\title{
Father Involvement: Construction of a Theoretical Model Based on a Literature Review
}

\author{
Ligia de Santis ${ }^{1}$ \\ Elizabeth Joan Barham \\ Universidade Federal de São Carlos, São Carlos, SP, Brazil
}

\begin{abstract}
An ample body of scientific evidence exists, documenting the importance of the father-child relationship. The objective of this study was to develop a theoretical model of father involvement, organized according to the principles of Structural Equation Modeling, which require specification of the variables associated with the central construct, based on empirical data. In 2015, a systematic search was conducted in the databases APA PsycNET, Bireme, PEPSIC, Web of Science and IndexPsi Periódicos, using the descriptors "involvement" and "father", crossed with "measure", "scale", "tool" or "instrument", in both the English and Portuguese languages. There were no restrictions on the year of publication. In total, 39 complete texts were located, that included data on father involvement. The information in these texts was grouped into three categories: (a) dimensions of father involvement, (b) factors affecting father involvement and (c) impacts of father involvement on other variables. The model presented synthesizes the results of these studies, representing an advance in theory development in this area. This model increases the visibility of conceptual issues about father involvement and its correlates, and, following empirical testing, may contribute to the improvement of intervention programs for fathers.
\end{abstract}

Keywords: Father involvement, theoretical model, development, wellbeing.

\section{Envolvimento Paterno: Construção de um Modelo Teórico Baseado em uma Revisão da Literatura}

\section{Resumo}

Um corpo amplo de evidências científicas já existente documenta a importância da relação pai-filho. O objetivo deste estudo foi desenvolver um modelo teórico de envolvimento paterno, organizado de acordo com princípios de Análise de Equações Estruturais, que requerem especificar as variáveis associadas ao construto central, com base em dados empíricos. Em 2015, foi realizada uma busca sistemática nas bases de dados eletrônicas APA PsycNET, Bireme, PEPSIC, Web of Science e IndexPsi Periódicos, usando os descritores "envolvimento" e "paterno", cruzados com "avaliação" ou "instrumento", nos idiomas inglês e português. Não foram impostas restrições em relação ao ano de publicação. Foram encontrados 39 textos completos que incluíam dados empíricos sobre o envolvimento paterno. As informações encontradas foram agrupadas em três categorias: (a) dimensões do envolvimento paterno, (b) fatores que afetam o envolvimento paterno e (c) impactos deste envolvimento sobre outras variáveis. O modelo apresentado sintetiza os resultados dos estudos e representa um avanço no desenvolvimento teórico na

Mailing address: Universidade Federal de São Carlos, Departamento de Psicologia, Rodovia Washington Luís, Km 235 - SP-310, São Carlos, SP, Brazil 13565-905. Phone: (16) 3351-8361. E-mail: ligiasantis@gmail.com We thank the Coordenação de Aperfeiçoamento de Pessoal de Nivel Superior [National Council for Higher Education Development] and the Fundação de Amparo à Pesquisa do Estado de São Paulo [Research Support Foundation of the State of São Paulo, Brazil], reference number 2014/01671-9, for their financial support. 
área. Este modelo aumenta a visibilidade de questões conceituais sobre o envolvimento paterno e seus correlatos, e, depois da sua testagem empírica, poderá contribuir para o aprimoramento de programas de intervenção para pais.

Palavras-chave: Envolvimento paterno, modelo teórico, desenvolvimento, bem-estar.

\section{Envolvimiento Paterno: Construcción de un Modelo Teórico Basado en una Revisión de la Literatura}

\section{Resumen}

Un cuerpo de evidencia científica ya existente documenta la importancia de la relación padre-hijo. El objetivo de este estudio fue desarrollar un modelo teórico de envolvimiento paterno, organizados de acuerdo con los principios de la Análisis de Ecuaciones Estructurales, que requieren especificar las variables asociadas con el constructo central, basada en datos empíricos. En 2015, se realizó una búsqueda sistemática en las bases de datos electrónicas APA PsycNET, Bireme, PEPSIC, Web of Science e IndexPsi Periódicos, utilizando los descriptores "envolvimento" y "paterno", cruzados con "avaliação" o "instrumento", en Inglés y Portugués. No hubo restricciones en el año de publicación. Se encontraron 39 textos completos que incluían datos empíricos sobre el envolvimiento paterno. Estos resultados se agruparon en tres categorías: (a) las dimensiones del envolvimiento paterno, (b) factores que afectan el envolvimiento paterno y (c) el impacto de este envolvimiento en otras variables. El modelo sintetiza los resultados de los estúdios y representa un avance en el desarrollo teórico del área. Este modelo aumenta la visibilidad de las cuestiones conceptuales sobre el envolvimiento paterno y sus correlatos, y, después de su comprobación empírica, puede contribuir a la mejora de los programas de intervención para los padres.

Palabras clave: Envolvimiento paterno, modelo teórico, desarrollo, bienestar.

Researchers' interest in studying father involvement is increasing, especially in recent decades (Volker, 2014). When initial studies on this question appeared in the academic literature, researchers focused on the effects of fathers' physical presence versus absence in the family environment (Cia, 2009), comparing indicators of child development in both situations. Starting in the 1990s, in addition to the focus on face to face interactions between fathers and their children, two further concepts were introduced: (a) accessibility, which captures the extent to which the father is both physically and psychologically available to his child, and (b) responsibility, which involves tasks that the father performs, to guarantee his child's care and welfare, such as taking the child to the doctor or maintaining relationships with paid caregivers (Lamb, 1997; Pleck, 2010). Currently, father involvement is understood as a multidimensional construct, covering a range of skills and encompassing affective, cognitive and ethical dimensions of the father-child relationship, and which involves observable behavioral components that can be either direct (father-child interactions) or indirect such as financial support, or psychological support to the mother (Pleck, 2007).

Although there is a considerable body of literature on the concept of father involvement, there is not yet a theoretical model of father involvement, indicating the relationship between this construct and other variables (Pleck, 2007; 2010). According to Pasquali (2010), the absence of an empirically-tested theoretical model makes it difficult to build effective tools to guide professional practice and to improve the quality of research in a given area.

A criterion for the construction of scientific, theoretical models is that they can be empirically tested. A psychometric approach to the development and evaluation of such models is through the use of Structural Equation Models 
(Byrne, 2010). Using this approach, initially the researcher examines empirical studies on the subject, to obtain evidence about the dimensions of the phenomenon of interest and relations between this phenomenon and other variables. Next, the researcher proposes a model that indicates probable links among these variables (Byrne, 2010; Kline, 2011). Thus, the objective of the present study was to construct an initial theoretical model of father involvement that integrates results of empirical studies, indicating: (a) the dimensions of father involvement, (b) factors that may affect father involvement, and (c) the possible impacts of father involvement on other constructs (outcomes).

\section{Method}

A literature search was conducted from February to March, 2015, using the following databases: APA PsycNET, Bireme, PEPSIC, Web of Science (using the portal de periódicos CAPES) and IndexPsi Periódicos. The descriptors used, in Portuguese, were: "envolvimento" and " $p a-$ terno" and "avaliação" or "instrumento". In English, the descriptors used were: "father" and "involvement" and "measure" or "instrument" or "scale" or "tool", with the aim of finding studies with empirical evidence on the subject. No limit was imposed on the date of publication. Only articles for which the full text could be acquired were considered for analysis, as articles must pass through a peer review process, to be published, and the full article contains important information that is unavailable in abstracts. In addition, the empirical information reported in these articles had to contribute to identifying: (a) the dimensions of father involvement, (b) factors that affect father involvement, or (c) impacts of father involvement on other variables. Two researchers analyzed the articles and reached a consensus (Anfara, Brown, \& Mangione, 2002) about the articles that met these criteria.

Of the 95 articles initially encountered, 41 were excluded because the full text was not available. During the analysis process, a further 15 articles were excluded, because they did not contain empirical results that were relevant to the objectives of this study, resulting in a final total of 39 articles for analysis.

\section{Results}

\section{Dimensions of Father Involvement}

To construct a unified theory of father involvement, it is important to examine how different researchers understand and operationalize this concept. In seven articles that focused on the creation or evaluation of psychometric instruments to measure father involvement, the authors examined empirical data to confirm or reject their expectations concerning this construct (see Table 1).

Wysocki and Gavin (2004), together with other authors, highlighted the importance of evaluating both the quantity and the quality of father involvement (Finley \& Schwartz, 2004; Gomez \& Leal, 2007). For example, Finley and Schwartz (2004), and Gomez and Leal (2007) analyzed the emotional quality of the fatherchild relationship, as experienced by the father.

In addition, father involvement includes "direct" activities, involving face-to-face interactions with the child, and "indirect" activities, encompassing tasks or interactions with others, in the interests of the child. With respect to direct involvement, Escribano et al. (2013) highlighted fathering practices related to child discipline and supervision. Finley and Schwartz (2004) also investigated direct fathering, focusing on actions related to the child's homework. In addition, they investigated indirect involvements, examining financial support provided to the family. In three of the studies (Dick, 2004; Halme et al., 2010; Ly \& Goldberg, 2014), father involvement was operationalized based on concepts proposed by Lamb (1997): interaction (direct involvements), accessibility and responsibility (indirect involvements).

Other scholars drew on more than one theory to construct their instruments. In addition to using Lamb's (1997) definition, Ly and Goldberg (2014), for example, examined fathers' cognitive involvement, while Dick (2004), Finley and Schwartz (2004), and Gomez and Leal (2007) 
investigated fathers' emotional involvement. Finally, Dick (2004) verified fathers' social functions (fathers' contributions to their child's social adaptation, involving moral, gender, and financial issues).

\section{Factors Affecting Father Involvement}

In 15 of the studies on father involvement, the researchers reported evidence on factors that appear to influence the father-child relationship. These factors are varied (see Table 2), including aspects of the father's general living conditions, together with indicators of the father's and the mother's characteristics and abilities.
Factors Related to the Fathers. Many investigators have examined characteristics of the fathers that affect the father-child relationship. Broger and Zeni (2011), for example, found that fathers who lived with their children were more strongly engaged parents, compared to those who did not reside with their children (Grzybowski \& Wagner, 2010). Although divorced fathers have a lower level of involvement, Warpechowski and Mosmann (2012) reported that these fathers had a positive view of their parenting role, and desired a greater participation in the lives of their children.

The father's age (Broger \& Zeni, 2011) and educational level (Grzybowski \& Wagner, 2010; Silva \& Aiello, 2009) are also correlated with

Table 1

Description of the Studies Grouped in the Category "Dimensions of Father Involvement".

\begin{tabular}{|c|c|c|c|c|}
\hline Reference & Country & Participants & $\begin{array}{l}\text { Child's } \\
\text { age }\end{array}$ & $\begin{array}{c}\text { Dimensions of father involvement that } \\
\text { were evaluated }\end{array}$ \\
\hline Wysocki \& Gavin (2004) & USA & $\begin{array}{l}224 \text { couples (father } \\
\text { and mother) - child } \\
\text { with a chronic disease }\end{array}$ & $\begin{array}{l}2-18 \\
\text { years }\end{array}$ & Quantity of father involvement \\
\hline $\begin{array}{l}\text { Finley \& Schwartz } \\
\qquad(2004)\end{array}$ & USA & 2353 men and women & $\mathrm{R}^{*}$ & $\begin{array}{c}\text { Measure 1: Quality of father's affective } \\
\text { involvement } \\
\text { Measure 2: Emotional, social, and spiritual } \\
\text { involvement; Financial, ethical responsible, } \\
\text { and protective involvement; Guidance in- } \\
\text { volvement }\end{array}$ \\
\hline Gomez \& Leal (2007) & Portugal & $\begin{array}{l}105 \text { fathers and } 107 \\
\text { mothers, during } \\
\text { pregnancy }\end{array}$ & $\mathrm{G}^{* *}$ & Prenatal attachment \\
\hline $\begin{array}{l}\text { Escribano, Aniorte, \& } \\
\text { Orgilés (2013) }\end{array}$ & Spain & 423 children & $\begin{array}{l}8-12 \\
\text { years }\end{array}$ & $\begin{array}{l}\text { Parental Involvement; Positive Parenting; } \\
\text { Inconsistent Discipline; Poor Supervision }\end{array}$ \\
\hline Dick (2004) & USA & 311 men & $\mathrm{R}^{*}$ & $\begin{array}{c}\text { Positive Engagement; Positive Emotional } \\
\text { Responsiveness; Negative Engagement; } \\
\text { Moral Father Role; Good Provider Role; } \\
\text { Gender Role Model; Androgynous Role } \\
\text { Model; Accessible Father; Responsible } \\
\text { Father }\end{array}$ \\
\hline $\begin{array}{l}\text { Halme, Tarkka, } \\
\text { Paavilainen, Nummi, \& } \\
\text { Åstedt-Kurki (2010) }\end{array}$ & Finland & 1084 fathers & $\begin{array}{l}3-6 \\
\text { years }\end{array}$ & $\begin{array}{l}\text { Shared activity of father and child; Enjoy- } \\
\text { ment of engagement; Potential engagement; } \\
\text { Daily confrontations related to engagement. }\end{array}$ \\
\hline Ly \& Goldberg (2014) & USA & $\begin{array}{l}101 \text { fathers of } \\
\text { children with } \\
\text { atypical } \\
\text { development }\end{array}$ & $\begin{array}{l}2-17 \\
\text { years }\end{array}$ & $\begin{array}{l}\text { Avoidance; Involvement with child's thera- } \\
\text { peutic activities }\end{array}$ \\
\hline
\end{tabular}

Note. $* \mathrm{R}=$ a retrospective study; participants described interactions they had with their parents, in the past. $* * \mathrm{G}=$ data were collected during the gestation of the child; the parents were expecting a child. 
Table 2

Description of the Studies Grouped in the Category "Factors that may Affect Father Involvement".

\begin{tabular}{|c|c|c|c|c|}
\hline Reference & Country & Participants & Child's age & $\begin{array}{l}\text { Factors affecting father } \\
\text { involvement }\end{array}$ \\
\hline Silva \& Aiello (2009) & Brazil & $\begin{array}{l}13 \text { fathers, each with a } \\
\text { mentally disabled child }\end{array}$ & $\begin{array}{l}2-4 \\
\text { years }\end{array}$ & Father: educational level \\
\hline $\begin{array}{l}\text { Brandão \& Figueiredo } \\
\text { (2012) }\end{array}$ & Portugal & 105 fathers & $\begin{array}{c}0-1 \\
\text { month }\end{array}$ & $\begin{array}{l}\text { Father: practical involvement } \\
\text { at the time of the child's birth }\end{array}$ \\
\hline Cia \& Barham (2006) & Brazil & 58 fathers & $\begin{array}{c}10-14 \\
\text { years }\end{array}$ & $\begin{array}{c}\text { Father: number of hours and work } \\
\text { period (work shift) }\end{array}$ \\
\hline $\begin{array}{l}\text { Warpechowski \& } \\
\text { Mosmann (2012) }\end{array}$ & Brazil & 3 divorced fathers & $\begin{array}{l}3-16 \\
\text { years }\end{array}$ & Father: marital status \\
\hline Broger \& Zeni (2011) & USA & $\begin{array}{l}54 \text { fathers of chronically } \\
\text { ill children }\end{array}$ & $\begin{array}{l}\text { Up to } 21 \\
\text { years }\end{array}$ & $\begin{array}{l}\text { Father: marital status, age, } \\
\text { and educational level }\end{array}$ \\
\hline $\begin{array}{l}\text { Grzybowski \& } \\
\text { Wagner }(2010)\end{array}$ & Brazil & $\begin{array}{l}234 \text { fathers and mothers, } \\
\text { following separation or } \\
\text { divorce }\end{array}$ & $\begin{array}{l}6-12 \\
\text { years }\end{array}$ & $\begin{array}{c}\text { Father: cohabiting with the child, } \\
\text { educational level, } \\
\text { type of occupation } \\
\text { Father-mother relationship: } \\
\text { quality of the marital relationship }\end{array}$ \\
\hline $\begin{array}{l}\text { Habib \& Lancaster } \\
\qquad(2010)\end{array}$ & Australia & $\begin{array}{l}78 \text { fathers - expecting } \\
\text { first child }\end{array}$ & $\mathrm{G}^{*}$ & $\begin{array}{l}\text { Father: father's emotional } \\
\text { involvement during the gestation } \\
\text { period }\end{array}$ \\
\hline $\begin{array}{l}\text { Van Ee, Sleijpen, } \\
\text { Kleber, \& Jongmans } \\
\text { (2013) }\end{array}$ & Netherlands & $\begin{array}{c}80 \text { fathers with } \\
\text { posttraumatic stress }\end{array}$ & $\begin{array}{l}18-42 \\
\text { months }\end{array}$ & Father: mental health \\
\hline $\begin{array}{l}\text { Cauce, Conger, King, } \\
\text { \& Widaman (2011) }\end{array}$ & USA & $\begin{array}{l}450 \text { children of two-parent } \\
\text { Mexican-origin families }\end{array}$ & $5^{\text {th }}$ grade & $\begin{array}{l}\text { Father: adherence to cultural } \\
\text { norms }\end{array}$ \\
\hline $\begin{array}{l}\text { Shapiro, Krysik, \& } \\
\text { Pennar (2011) }\end{array}$ & USA & $\begin{array}{l}197 \text { mothers whose } \\
\text { families were at risk for } \\
\text { child abuse }\end{array}$ & 3 months & $\begin{array}{l}\text { Father: capacity to deal } \\
\text { with financial tasks }\end{array}$ \\
\hline $\begin{array}{l}\text { Waller \& Bitler } \\
\qquad(2008)\end{array}$ & USA & $\begin{array}{l}3103 \text { unmarried, expecting } \\
\text { fathers and mothers }\end{array}$ & Newborn & Father: abortion intention \\
\hline $\begin{array}{l}\text { Murray, Rosengard, } \\
\text { Weitzen, Raker, \& } \\
\text { Phipps (2012) }\end{array}$ & USA & $\begin{array}{l}300 \text { pregnant, } \\
\text { teenage mothers } \\
(12-19 \text { years old })\end{array}$ & $\mathrm{G}^{*}$ & $\begin{array}{l}\text { Father: support given to the } \\
\text { mother during pregnancy, } \\
\text { practical involvement at time } \\
\text { of birth } \\
\text { Mothers: sociodemographic } \\
\text { characteristics }\end{array}$ \\
\hline $\begin{array}{c}\text { Falceto, Fernandes, } \\
\text { Baratojo, \& Giugliani } \\
\text { (2008) }\end{array}$ & Brazil & 153 families & 4 months & $\begin{array}{l}\text { Mother: if she has paid work } \\
\text { Father-mother relationship: } \\
\text { quality of the marital relationship }\end{array}$ \\
\hline $\begin{array}{l}\text { Ehrenberg, } \\
\text { Gearing-Small, } \\
\text { Hunter, \& Small } \\
\text { (2001) }\end{array}$ & Canada & $\begin{array}{l}58 \text { dual-earner } \\
\text { couples }\end{array}$ & $\begin{array}{l}\text { Up to } 9 \\
\text { years }\end{array}$ & $\begin{array}{l}\text { Father-mother relationship: } \\
\text { shared parenting }\end{array}$ \\
\hline $\begin{array}{l}\text { Formoso, Gonzales, } \\
\text { Barrera, \& Dumka } \\
\text { (2007) }\end{array}$ & USA & $\begin{array}{l}115 \text { Mexican American } \\
\text { two-parent families }\end{array}$ & $\begin{array}{l}11-14 \\
\text { years }\end{array}$ & $\begin{array}{l}\text { Father-mother relationship: } \\
\text { quality of the marital relationship; } \\
\text { parenting alliance }\end{array}$ \\
\hline
\end{tabular}

Note. ${ }^{*} \mathrm{G}=$ data were collected during the gestation of the child; the parents were expecting a child. 
father involvement; the greater the father's age and educational level, the greater his parenting involvement. Moreover, the greater the father's ability to provide for his family (reflected in family income and car ownership), the higher the level of father involvement (Shapiro et al., 2011). The father's mental health also affects his parenting involvement. Van Ee et al. (2013) demonstrated the negative influence of posttraumatic stress on the quality of the fatherchild relationship.

In addition to the home front situation and the father's sociodemographic profile, researchers have also investigated the influence of the father's paid job on his parenting involvement. Type of occupation (Grzybowski \& Wagner, 2010), number of hours spent working and the timing of work hours (work shift; Cia \& Barham, 2006) all affect father involvement; a greater number of hours at home during the child's nonschool, waking hours is associated with greater parenting involvement.

Other researchers have studied the earliest indicators of parenting behaviors as predictors of involvement levels, later on. The same as mothers, a father's involvement with his child starts during pregnancy (Piccinini, Silva, Gonçalves, Lopes, \& Tudge, 2004). Intentions to terminate a pregnancy, among unmarried fathers and mothers, are related to a reduced probability that the father will help to meet expenses associated with the pregnancy, for example (Waller \& Bitler, 2008). On the other hand, the more intense the father's emotional involvement during the gestation period (Habib \& Lancaster, 2010) the greater: (a) the support he gives to the mother (Murray et al., 2012), (b) his practical involvement at the time of his child's birth (Brandão \& Figueiredo, 2012; Murray et al., 2012), and (c) the likelihood that the father will engage in parenting activities at the beginning of his child's life.

Finally, Cauce et al. (2011) examined the influence of cultural norms on the father-child relationship. When children evaluated their father's involvement, fathers who adhered to cultural norms regarding their family responsibilities were evaluated more positively.

Factors Related to the Mothers. Murray et al. (2012) observed that the mother's sociode- mographic characteristics (such as race, age, and country of birth) affect the probability that the father will register the birth of their child, which is a critical step for fathers to establish a longterm involvement with their child. Maternal employment is also important. Falceto et al. (2008) noted that when mothers did not have a paid job, there was a lower probability of the fathers being involved with their child, than when the mothers were economically active.

Factors Related to the Relationship Between the Child's Father and Mother. Falceto et al. (2008), Formoso et al. (2007), and Grzybowski and Wagner (2010) found that poor quality marital relationships are associated with low fathering involvement. On the other hand, a constructive alliance between the father and the mother positively influenced the quality of the father-child relationship (Formoso et al., 2007). In addition, the ability of the couple to engage in shared parenting (through cooperation and mutual support) was also positively related to father involvement (Ehrenberg et al., 2001).

\section{Outcomes of Father Involvement}

In addition to the evidence on factors that may affect father involvement, in 19 papers, the authors presented results that point to developmental outcomes for the children, their mothers, their fathers or for the family as a whole, that may be affected by father involvement (see Table 3). For each family member, the evidence points to multiple impacts on the person's life.

Outcomes of Father Involvement for the Children. Bronte-Tinkew et al. (2006), Cia and Barham (2009), Cia, Barham and Fontaine (2010), Formoso et al. (2007), Freeze et al. (2014) and Ramchandani et al. (2013) reported negative relationships between the quality of father involvement and the occurrence or frequency of the following difficulties, among their children: (a) mental health problems (such as depression), (b) externalizing behaviors (negative behaviors directed towards others), (c) internalizing behaviors (self-directed, negative behaviors), or (d) hyperactivity. For example, Uji et al. (2014) reported that children with authoritarian fathers (with a lower quality of 
Table 3

Description of the Studies Grouped in the Category "Outcomes of Father Involvement".

\begin{tabular}{|c|c|c|c|c|}
\hline Reference & Country & Participants & $\begin{array}{l}\text { Child's } \\
\text { age }\end{array}$ & Outcomes of Father Involvement \\
\hline $\begin{array}{l}\text { Ramchandani et al. } \\
\qquad(2013)\end{array}$ & $\begin{array}{l}\text { United } \\
\text { Kingdom }\end{array}$ & 192 families & 1 year & Child: externalizing behaviors \\
\hline $\begin{array}{l}\text { Cia, Barham, \& } \\
\text { Fontaine }(2010)\end{array}$ & Brazil & $\begin{array}{l}20 \text { teachers, } \\
99 \text { children (whose } \\
\text { fathers participated } \\
\text { in an intervention } \\
\text { program) }\end{array}$ & $\begin{array}{l}8 \text { years } \\
\text { (average) }\end{array}$ & $\begin{array}{c}\text { Child: externalizing and internalizing } \\
\text { behaviors }\end{array}$ \\
\hline $\begin{array}{l}\text { Cia \& Barham } \\
\text { (2009) }\end{array}$ & Brazil & $\begin{array}{l}97 \text { couples } \\
\text { (father and mother) } \\
\text { and } 20 \text { teachers }\end{array}$ & $\begin{array}{l}6-9 \\
\text { years }\end{array}$ & $\begin{array}{l}\text { Child: hyperactivity, externalizing } \\
\text { and internalizing behaviors }\end{array}$ \\
\hline $\begin{array}{l}\text { Bronte-Tinkew, } \\
\text { Moore, Capps, \& } \\
\text { Zaff }(2006)\end{array}$ & USA & $\begin{array}{l}7242 \text { children } \\
\text { (teenagers) }\end{array}$ & $\begin{array}{l}\text { Up to } 18 \\
\text { years }\end{array}$ & Child: externalizing behaviors \\
\hline $\begin{array}{l}\text { Freeze, Burke, \& } \\
\text { Vorster (2014) }\end{array}$ & $\begin{array}{l}\text { South } \\
\text { Africa }\end{array}$ & $\begin{array}{l}80 \text { male } \\
\text { children }\end{array}$ & $14-18$ years & Child: externalizing behaviors \\
\hline $\begin{array}{l}\text { Cia, Barham, \& } \\
\text { Fontaine }(2012)\end{array}$ & Brazil & $\begin{array}{l}97 \text { couples (father } \\
\text { and mother) }\end{array}$ & $6-9$ years & $\begin{array}{l}\text { Child: academic achievement, } \\
\text { self-concept }\end{array}$ \\
\hline $\begin{array}{l}\text { Falco, Esposito, } \\
\text { Venuti, \& } \\
\text { Bornstein (2008) }\end{array}$ & Italy & 19 children & $\begin{array}{l}35.3 \text { months } \\
\text { (average) }\end{array}$ & $\begin{array}{c}\text { Child: emergence of symbolic } \\
\text { behavior }\end{array}$ \\
\hline $\begin{array}{l}\text { Salonna et al. } \\
\qquad(2012)\end{array}$ & Slovakia & 1863 children & $\begin{array}{l}\text { 16.8years } \\
\text { (average) }\end{array}$ & Child: overall health \\
\hline $\begin{array}{l}\text { Uji, Sakamoto, } \\
\text { Adachi, \& } \\
\text { Kitamura (2014) }\end{array}$ & Japan & 1320 adults & $\mathrm{R}^{*}$ & $\begin{array}{l}\text { Child: depression, anxiety, symptoms } \\
\text { of stress-related health problems, } \\
\text { social functioning, psychological } \\
\text { wellbeing }\end{array}$ \\
\hline $\begin{array}{l}\text { Formoso et al. } \\
\qquad(2007)\end{array}$ & USA & $\begin{array}{c}115 \text { Mexican } \\
\text { American two-parent } \\
\text { families }\end{array}$ & $11-14$ years & $\begin{array}{l}\text { Child: mental health (depression), } \\
\text { externalizing behaviors }\end{array}$ \\
\hline $\begin{array}{c}\text { Cerniglia, } \\
\text { Cimino, } \& \\
\text { Ballarotto }(2014)\end{array}$ & Italy & 77 families & $\begin{array}{l}23-26 \\
\text { months }\end{array}$ & $\begin{array}{l}\text { Child: quality of the father-child } \\
\text { relationship during meals, when } \\
\text { the father fed the child }\end{array}$ \\
\hline $\begin{array}{l}\text { Tessier et al. } \\
\qquad(2009)\end{array}$ & Colombia & 338 families & 1 year & $\begin{array}{l}\text { Child: locomotor, social, speech, } \\
\text { hearing and motor coordination } \\
\text { development } \\
\text { Family: environmental stimulation, } \\
\text { social openness, and positivity of the } \\
\text { mother-child interactions }\end{array}$ \\
\hline $\begin{array}{c}\text { Séjourné, } \\
\text { Beaumé, } \\
\text { Vaslot, \& } \\
\text { Chabrol }(2012)\end{array}$ & France & $\begin{array}{l}51 \text { couples (father } \\
\text { and mother) }\end{array}$ & $\begin{array}{c}0-4 \\
\text { months }\end{array}$ & Mother: postpartum depression \\
\hline $\begin{array}{l}\text { Fagan \& Lee } \\
\qquad(2010)\end{array}$ & USA & $\begin{array}{c}100 \text { teenage } \\
\text { mothers }\end{array}$ & $\begin{array}{c}0-3 \\
\text { months }\end{array}$ & Mother: postpartum depression \\
\hline
\end{tabular}




\begin{tabular}{|c|c|c|c|c|}
\hline Reference & Country & Participants & $\begin{array}{l}\text { Child's } \\
\text { age }\end{array}$ & Outcomes of Father Involvement \\
\hline $\begin{array}{l}\text { Séjourné, Vaslot, } \\
\text { Beaumé, } \\
\text { Goutaudier, \& } \\
\text { Chabrol (2012) }\end{array}$ & France & $\begin{array}{l}119 \text { couples } \\
\text { (father and mother) }\end{array}$ & $\begin{array}{c}0-2 \\
\text { months }\end{array}$ & Mother: postpartum depression \\
\hline $\begin{array}{l}\text { Alexander, } \\
\text { O’Riordan, \& } \\
\text { Furman }(2010)\end{array}$ & USA & $\begin{array}{c}176 \text { low-income, preg- } \\
\text { nant couples }\end{array}$ & $\mathrm{G}^{* *}$ & $\begin{array}{l}\text { Mother: intention and involvement } \\
\text { in breastfeeding }\end{array}$ \\
\hline $\begin{array}{l}\text { Shapiro et al. } \\
\qquad(2011)\end{array}$ & USA & $\begin{array}{l}197 \text { mothers whose } \\
\text { families were at risk for } \\
\text { child abuse }\end{array}$ & 3 months & $\begin{array}{l}\text { Mother: sense of loneliness } \\
\text { Family: prenatal care, cases of } \\
\text { domestic violence, family income }\end{array}$ \\
\hline $\begin{array}{l}\text { Bonner, Hardy, } \\
\text { Willard, \& } \\
\text { Hutchinson (2007) }\end{array}$ & USA & $\begin{array}{l}23 \text { fathers (primary } \\
\text { caregivers of a child } \\
\text { with a chronic illness) }\end{array}$ & $\begin{array}{l}9.5 \text { years } \\
\text { (average) }\end{array}$ & $\begin{array}{c}\text { Father: psychological distress, } \\
\text { depression }\end{array}$ \\
\hline $\begin{array}{l}\text { Frascarolo, } \\
\text { Zaouche-Gaudron, } \\
\& \text { Favez (2005) }\end{array}$ & Switzerland & $\begin{array}{l}13 \text { fathers } \\
\text { (first child) }\end{array}$ & $\begin{array}{l}0-18 \\
\text { months }\end{array}$ & Family: family alliance \\
\hline
\end{tabular}

Note. $* \mathrm{R}=$ a retrospective study; participants described interactions they had with their parents, in the past. $* * \mathrm{G}=$ data were collected during the gestation of the child; the parents were expecting a child.

involvement) showed more unfavorable results on measures of depression, anxiety, physical symptoms, social functioning and psychological wellbeing.

In addition to these impacts on children's psychological wellbeing, children whose fathers had lower levels of involvement tended to have weaker academic achievement levels and a poorer self-concept (Cia et al., 2012). On the positive side, Falco et al. (2008) observed that fathers' positive involvement favored the emergence of symbolic behavior among children with Down syndrome. Other positive consequences of more frequent father involvement include greater overall health of the children (Salonna et al., 2012). In this sense, fathers with a higher quality father-child relationship reported fewer difficulties in feeding their two-year old child (Cerniglia et al., 2014). In a more comprehensive study, Tessier et al. (2009) found that when father involvement was high, it had a positive effect on the development of male children in the following areas: locomotor, social, speech, hearing and motor coordination.

Outcomes of Father Involvement for the Mothers. Researchers found that the more lim- ited the father's initial involvement, or the lower the mother's satisfaction with this involvement, the more intense the symptoms of maternal postpartum depression (Fagan, \& Lee, 2010; Séjourné, Beaumé, et al., 2012; Séjourné, Vaslot, et al., 2012) and the greater the sense of maternal loneliness (Shapiro et al., 2011). In addition, Alexander et al. (2010), found that the father's support significantly influenced the mother's intention and subsequent involvement in breastfeeding.

Outcomes of Father Involvement for the Fathers. In the current literature review, Bonner et al. (2007) conducted the only study on the effects of father involvement on the fathers, themselves. These researchers studied fathers whose children had cancer. Fathers with a greater level of involvement reported greater psychological distress and higher levels of depression. There were no studies about outcomes of parenting involvement for fathers of children with typical development.

Outcomes of Father Involvement for the Family Environment. Tessier et al. (2009) found that families with more involved fathers were assessed as providing more stimulating 
environments, were more open to other people (such as the extended family and neighbors), and had more positive mother-child interactions. Frascarolo et al. (2005) reported stronger family alliances when the father was more participative. In a third study, Shapiro et al. (2011) found associations between positive father involvement and: (a) better prenatal care during pregnancy, (b) fewer cases of domestic physical violence, and (c) higher family income.

\section{Discussion}

This literature review indicates that researchers have expanded the concept of father involvement and have gathered empirical evidence supporting the relationship between a variety of conditions that may affect father involvement, as well as a range of potential outcomes. Investigators have shown that differences in father involvement may be related to antecedent conditions such as age, education, marital status, and health conditions of the fathers and mothers, and to the quality of the relationship between the two parents. In addition, there are significant developmental outcomes associated with father involvement, mostly for their children, but also for the mothers and for the fathers themselves. Taken together, this empirical evidence can be used to construct an initial theoretical model of father involvement.

The results of this literature review generally confirm the results reported by Gomes, Bossardi, Cruz, Crepaldi and Vieira (2014), who compared information about different instruments that are being used to assess father involvement. Based on an analysis of 15 scientific papers, these authors emphasized the importance of Lamb's (1997) tripartite concept of fathering (interaction, accessibility and responsibility), which provided a conceptual framework for most of the measures they encountered. However, some instruments were also constructed to evaluate more specific dimensions of the father-child relationship, such as emotional (or affective) involvement, parenting practices (discipline and educational involvement), and father-child communication. Gomes et al. discussed the impor- tance of assessing these dimensions to capture both the quality and quantity of the father's engagement. In the articles reviewed in the current study, additional dimensions were described, including the cognitive and social dimensions of fathering, and indirect fathering involvements. In addition to further expanding our understanding of father involvement, we also examined information about factors that may either affect or be affected by father involvement.

The information found in a systematic literature review depends on the descriptors that are used. For example, in this review, none of the researchers assessed father involvement in terms of the extent to which the father physically stimulated his child. According to Manfroi, Macarini and Vieira (2011), the most frequent type of father-child interaction is active play (a physical dimension of paternal involvement), which is important for child development. In addition, characteristics of the children (such as their social skills) were not investigated in any of the studies that comprised this review, although other authors have shown that child-related factors such as social responsiveness can modify father involvement (Mehall, Spinrad, Eisenberg \& Gaertner, 2009; Volker, 2014). The absence of this information may be linked to the descriptors used in this study, as some authors may have used more general descriptors (such as "child development"), or have used other descriptors (such as "father engagement"). Thus, in order to present a more complete theoretical model (see Figure 1), these two additional concepts were included (in boxes with broken perimeter lines), together with the concepts described in the results of this study.

As shown in Figure 1, father involvement may function as an intervening variable, which modifies the impact of the contextual conditions and abilities of the parents on the development and welfare of the child, the father, and the mother. With respect to factors that affect father involvement, the evidence was organized to capture the influence of personal, social and cultural characteristics of each of the parents, individually, as well as the quality of the relationship between them, which is coherent with theo- 
FACTORS AFFECTING FATHER INVOLVEMENT

\begin{tabular}{|c|}
\hline Father \\
Cohabiting with the child \\
Access to information \\
(educational level) \\
Expectations and life experiences \\
(age, culture) \\
Availability of time and financial \\
resources \\
Initial mental health \\
Work conditions \\
Early fatherhood involvement \\
\hline Mother \\
Expectations and life experiences \\
(age, culture) \\
Work conditions
\end{tabular}

$\begin{gathered}\text { Father-mother relationship } \\ \text { Affective-marital issues } \\ \text { Shared parenting }\end{gathered}$
Child
Social responsiveness/social skills, etc.
FATHER

INVOLVEMENT

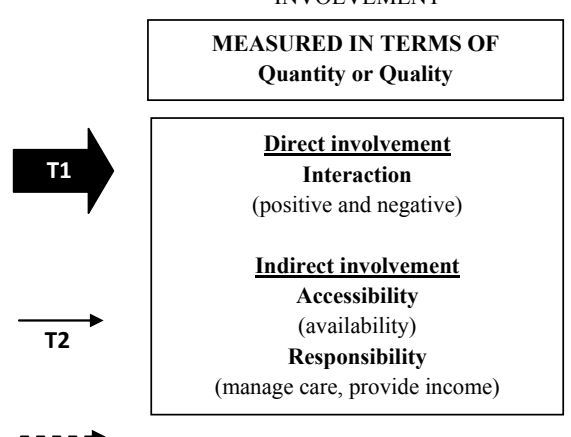

$-\overline{\mathrm{Tn}}-\rightarrow$

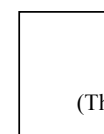

\section{DIMENSIONS} Cognitive

(Thoughts concerning the child) Emotional

(Emotional engagement) Social

(Shaping the child's social adjustment)

Physical stimulation of child

OUTCOMES OF FATHER INVOLVEMENT

Child development Mental health Social performance

Cognitive functioning

Academic achievement

\section{$\begin{gathered}\text { Self-concept } \\ \text { Physical development }\end{gathered}$
T1 \\ $\begin{gathered}\text { Self-concept } \\ \text { Physical development }\end{gathered}$
T1}

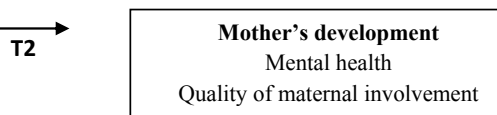

$-\overline{\mathrm{T} n}-\rightarrow$

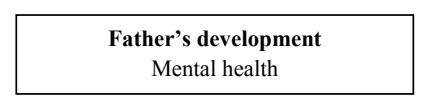

her's developme

mily environment Social openness

Family alliance

Domestic violence

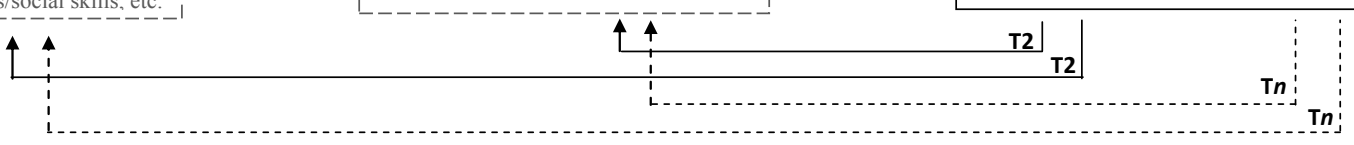

Figure 1. Theoretical model of father involvement. Conditions at Time 1 (T1) affect father involvement, which, in turn, modifies outcomes for each family member. These outcomes spur adjustments to fathering conditions or involvements, at Time 2 (T2), and so on, over time (Tn).

retical considerations presented by other authors (Cabrera, Shannon, \& Tamis-Lemonda, 2007; Volker, 2014). In terms of outcomes associated with differences in the quality of the father-child relationship, the evidence suggests that father involvement is associated with developmental outcomes for all family members. Child development outcomes were the most commonly reported, which is consistent with the findings of other authors who have investigated factors affecting child development (Cabrera et al., 2007; Lamb, 2010; Volker, 2014).

Based on our analysis and synthesis of the empirical evidence on father involvement, we propose a theoretical model that specifies the relationship between father involvement and other variables, helping to identify important correlates that can contribute to future work on this topic. Information about the impacts of the father-child relationship on children, mothers, and fathers point to the potential benefits of intervention programs to help fathers be more constructively involved parents. However, this model now needs to be empirically tested, us- ing a structural equation modeling approach. In addition, experimental, intervention studies are needed to determine whether there are causal relationships between the antecedent conditions specified in the model and the quality of father involvement, and if increases in father involvement lead to improved outcomes. In closing, the use of an evidence-based, comprehensive, theoretical model of father involvement can make a significant contribution to increasing the effectiveness of interventions to improve the quality of father-child relationships.

\section{References}

*Alexander, A., O'Riordan, M. A., \& Furman, L. (2010). Do breastfeeding intentions of pregnant inner-city teens and adult women differ. Breastfeeding Medicine, 5(6), 289-296. doi:10.1089/ bfm.2009.0083

Anfara, V. A., Brown, K. M., \& Mangione, T. L. (2002). Qualitative analysis on stage: Making the research process more public. Educational Researcher, 31, 28-38. doi:10.3102/0013189X031007028 
*Bonner, M. J., Hardy, K. K., Willard, V. W., \& Hutchinson, K. C. (2007). Brief report: Psychosocial functioning of fathers as primary caregivers of pediatric oncology patients. Journal of Pediatric Psychology, 32(7), 851-856. doi:10.1093/jpepsy/jsm011

*Brandão, S., \& Figueiredo, B. (2012). Fathers' emotional involvement with the neonate: Impact of the umbilical cord cutting experience. Journal of Advanced Nursing, 68(12), 2730-2739. doi:10.1111/j.1365-2648.2012.05978.x

*Broger, B., \& Zeni, M. B. (2011). Fathers' coping mechanisms related to parenting a chronically Ill child: Implications for advanced practice nurses. Journal of Pediatric Health Care, 25(2), 96104. doi:10.1016/j.pedhc.2009.09.004

*Bronte-Tinkew, J., Moore, K. A., Capps, R. C., \& Zaff, J. (2006). The influence of father involvement on youth risk behaviors among adolescents: A comparison of native-born and immigrant families. Social Science Research, 35, 181-209. doi:10.1016/j.ssresearch.2004.08.002

Byrne, B. M. (2010). Structural Equation Modeling with AMOS. Basic concepts, applications, and programmimng ( $2^{\text {nd }}$ ed.). New York: Routledge, Taylor \& Francis Group.

Cabrera, N. J., Shannon, J. D., \& Tamis-Lemonda, C. (2007). Father's influence on their children's cognitive and emotional development: From toddlers to pre-K. Applied Development Science, 11(4), 208-213. doi:10.1080/10888690701762100

*Cauce, A. M., Conger, R. D., Cruz, R. A., King, K. M., \& Widaman, K. F. (2011). Cultural influences on positive father involvement in two-parent Mexican-origin families. Journal of Family Psychology, 25(5), 731-740. doi:10.1037/a0025128

*Cerniglia, L., Cimino, S., \& Ballarotto, G. (2014). Mother-child and father-child interaction with their 24-month-old children during feeding, considering paternal involvement and the child's temperament in a community sample. Infant Mental Health Journal, 35(5), 473-481. doi:10.1002/imhj.21466

Cia, F. (2009). Um programa para aprimorar o envolvimento paterno: Impactos no desenvolvimento do filho [A program to improve paternal involvement: Impacts on child development] (Doctoral thesis, Postgraduate Program in Special Education, Federal University of São Carlos, São Carlos, SP, Brazil).
*Cia, F., \& Barham, E. J. (2006). Influências das condições de trabalho do pai sobre o relacionamento pai-filho [Influences of the father's work conditions on the father-child relationship]. Psico-USF, 11(2), 257-264. doi:10.1590/S141382712006000200014

*Cia, F., \& Barham, E. J. (2009). O envolvimento paterno e o desenvolvimento social de crianças iniciando as atividades escolares [Father involvement and the social development of children in the school-entry transition stage]. Psicologia em Estudo, 14(1), 67-74. doi:10.1590/S141373722009000100009

*Cia, F., Barham, E. J., \& Fontaine, A. M. G. V. (2010). Impactos de uma intervenção com pais: O desempenho acadêmico e comportamento das crianças na escola [Impacts of a parent intervention program: Their children's academic achievement and classroom behavior]. Psicologia: Reflexão e Crítica, 23(3), 533-543. doi:10.1590/S0102-79722010000300014

*Cia, F., Barham, E. J., \& Fontaine, A. M. G. V. (2012). Desempenho acadêmico e autoconceito de escolares: Contribuições do envolvimento paterno [Children's academic performance and self-concept: Contributions of father involvement]. Estudos de Psicologia (Campinas), 29(4),461-470. doi:10.1590/S0103-166X2012000400001

*Dick, G. L. (2004). The Fatherhood Scale. Research on Social Work Practice, 14(2), 80-92. doi:10.1177/1049731503257863

*Ehrenberg, M. F., Gearing-Small, M., Hunter, M. A., \& Small, B. J. (2001). Childcare task division and shared parenting attitudes in dualearner families with young children. Family Relations, 50(2), 143-153. doi:10.1111/j.17413729.2001.00143.x

*Escribano, S., Aniorte, J., \& Orgilés, M. (2013). Factor structure and psychometric properties of the Spanish version of the Alabama Parenting Questionnaire (APQ) for children. Psicothema, 25(3), 324-329.doi:10.7334/psicothema2012.315

*Fagan, J., \& Lee, Y. (2010). Perceptions and satisfaction with father involvement and adolescent mothers' postpartum depressive symptoms. Journal on Youth and Adolescence, 39, 11091121. doi:10.1007/s10964-009-9444-6

*Falceto, O. G., Fernandes, C. L., Baratojo, C., \& Giugliani, E. R. J. (2008). Factors associated with father involvement in infant care. Revista 
Saúde Pública, 42(6), 1-6. doi:10.1590/S003489102008000600009

*Falco, S. de, Esposito, G., Venuti, P., \& Bornstein, M. H. (2008). Fathers' play with their Down's syndrome children. Journal of Intellectual Disability Research, 52(6), 490-502. doi:10.1111/ j.1365-2788.2008.01052.x

*Finley, G. E., \& Schwartz, S. J. (2004). The Father Involvement and Nurturant Fathering Scales: Retrospective measures for adolescent and adult children. Educational and Psychological Measurement, 64(1), 143-164. doi:10.1177/0013164403258453

*Formoso, D., Gonzales, N. A., Barrera, M., Jr., \& Dumka, L. E. (2007). Interparental relations, maternal employment, and fathering in Mexican-American families. Journal of Marriage and the Family, 69, 26-39. doi:10.1111/j.17413737.2006.00341.x

*Frascarolo, F., Zaouche-Gaudron, C., \& Favez, N. (2005). Variations in fathers' discourse on fatherhood and in family alliances during infancy. European Journal of Psychology of Education, 20(2), 185-199. doi:10.1007/BF03173507

*Freeze, M. K., Burke, A., \& Vorster, A. C. (2014). The role of parental style in conduct disorders: A comparison between adolescent boys with and without conduct disorders. Journal of Child \& Adolescent Mental Health, 26(1), 63-73. doi:10. 2989/17280583.2013.865627

Gomes, L. B., Bossardi, C. N., Cruz, R. M., Crepaldi, M. A., \& Vieira, M. L. (2014). Propriedades psicométricas de instrumentos de avaliação do envolvimento paterno: Revisão de literatura [The psychometric properties of instruments for evaluating father involvement: A literature review]. Avaliação Psicológica, 13(1), 19-27. Retrieved from http://pepsic.bvsalud.org/pdf/avp/v13n1/ v13n1a04.pdf

*Gomez, R., \& Leal, I. (2007). Vinculação parental durante a gravidez: Versão portuguesa da forma materna e paterna da Antenatal Emotional Attachment Scale [Parental attachment during pregnancy: The Portuguese maternal and paternal versions of the Antenatal Emotional Attachment Scale]. Psicologia, Saúde \& Doenças, $8(2)$, 153-165. Retrieved from http://www.scielo.mec.pt/pdf/psd/v8n2/v8n2a01.pdf

*Grzybowski, L. S., \& Wagner, A. (2010). O envolvimento parental após a separação/divórcio [Paternal involvement following separation or divorce].
Psicologia: Reflexão e Crítica, 23(2), 289-298. doi:10.1590/S0102-79722010000200011

*Habib, C., \& Lancaster, S. (2010). Changes in identity and paternal-foetal attachment across a first pregnancy. Journal of Reproductive and Infant Psychology, 28(2), 128-142. doi:10.1080/02646830903298723

*Halme, N., Tarkka, M. T., Paavilainen, E., Nummi, T., \& Åstedt-Kurki, P. (2010). The design and development of the father-child instrument (FCI) for assessing the characteristics of fathers' availability and engagement with their preschool children. American Journal of Men's Health, 4(2), 145-156. doi:10.1177/1557988309331825

Kline, R. B. (2011). Principles and Practice of Structural Equation Modeling (3 ${ }^{\text {rd }}$ ed.). New York: The Guilford Press.

Lamb, M. E. (1997). Father and child development: An introductory overview and guide. In M. E. Lamb (Ed.), The Role of the Father in Child Development (pp. 1-18). New York: John Wiley \& Sons.

Lamb, M. E. (2010). How do fathers influence children's development? Let me count the ways. In M. E. Lamb (Ed.), The Role of the Father in Child Development ( $2^{\text {nd }}$ ed., pp. 1-26). Hoboken, NJ: John Wiley \& Sons.

*Ly, A. R., \& Goldberg, W. A. (2014). A new measure for fathers of children with developmental challenges. Journal of Intellectual Disability Research, 58(5), 471-484. doi:10.1111/jir.12044

Manfroi, E. C., Macarini, S. M., \& Vieira, M. L. (2011). Comportamento parental e o papel do pai no desenvolvimento infantil [Parental behavior and the role of the father in child development]. Revista Brasileira Crescimento e Desenvolvimento Humano, 21(1), 59-69. Retrieved from http://pepsic.bvsalud.org/scielo.php?script=sci arttext\&pid=S0104-12822011000100007

Mehall, K. G., Spinrad, T. L., Eisenberg, N., \& Gaertner, B. M. (2009). Examining the relations of infant temperament and couples' marital satisfaction to mother and father involvement: A longitudinal study. Fathering, 7(1), 23-48. doi: $10.3149 / \mathrm{fth} .0701 .23$

Murray, A. L., Rosengard, C., Weitzen, S., Raker, C. A., \& Phipps, M. G. (2012). Demographic and relationship predictors of paternity establishment for infants born to adolescent mothers. Pediatric and Adolescent Gynecology, 25, 322327. doi:10.1016/j.jpag.2012.05.015 
Pasquali, L. (2010). Instrumentação psicológica: Fundamentos e práticas [Psychological instrumentation: Principles and practices]. Porto Alegre, RS: Artmed.

Piccinini, C. A., Silva, M. R., Gonçalves, T. R., Lopes, R. L., \& Tudge, J. (2004). O envolvimento paterno durante a gestação [Paternal involvement during the gestational period]. Psicologia: Reflexão e Crítica, 17(3), 303-314. doi:10.1590/ S0102-79722004000300003

Pleck, J. H. (2007). Why could father involvement benefit children? Theoretical perspectives. Applied Development Science, 11(4), 196-202. doi: $10.1080 / 10888690701762068$

Pleck, J. H. (2010). Paternal involvement: Revised conceptualization and theoretical linkages with child outcomes. In M. E. Lamb (Ed.), The Role of the Father in Child Development ( $2^{\text {nd }}$ ed., pp. 28-58). Hoboken, NJ: John Wiley \& Sons.

*Ramchandani, P. G., Domoney, J., Sethna, V., Psychogiou, L., Vlachos, H., \& Murray, L. (2013). Do early father-infant interactions predict the onset of externalizing behaviors in young children? Findings from a longitudinal cohort study. Journal of Child Psychology and Psychiatry, 54(1), 56-64. doi:10.1111/j.1469-7610.2012.02583.x

*Salonna, F., Geckova, A. M., Zezula, I., Sleskova, M., Groothoff, J. W., Reijneveld, S. A., \& van Dijk, J. P. (2012). Does social support mediate or moderate socioeconomic differences in self-rated health among adolescents? International Journal of Public Health, 57, 609-617. doi:10.1007/s00038-011-0300-6

*Séjourné, N., Beaumé, M., Vaslot, V., \& Chabrol, H. (2012). Effect of paternity leave on maternal postpartum depression. Gynécologie Obstétrique \& Fertilité, 40, 360-364. doi:10.1016/j. gyobfe.2011.08.033

*Séjourné, N., Vaslot, V., Beaumé, M., Goutaudier, N., \& Chabrol, H. (2012). The impact of paternity leave and paternal involvement in childcare on maternal postpartum depression. Journal of Reproductive and Infant Psychology, 30(2), 135-144. doi:10.1080/02646838.2012.693155

*Shapiro, A. F., Krysik, J., \& Pennar, A. L. (2011). Who are the fathers in healthy families in Arizona? An examination of father data in atrisk families. American Journal of Orthopsychiatry, 81(3), 327-336. doi: 10.1111/j.19390025.2011.01101.x
*Silva, N. C. B., \& Aiello, A. R. L. (2009). Análise descritiva do pai da criança com deficiência mental [Descriptive analysis of fathering a mentally disabled child]. Estudos de Psicologia (Campinas), 26(4), 493-503. doi:10.1590/ S0103-166X2009000400010

*Tessier, R., Charpak, N., Giron, M., Cristo, M., Calume, Z. F., \& Ruiz-Peláez, J. G. (2009). Kangoroo mother care, home environment and father involvement in the first year of life: A randomized controlled study. Acta Pcediatrica, 98, 14441450. doi:10.1111/j.1651-2227.2009.01370.x

*Uji, M., Sakamoto, A., Adachi, K., \& Kitamura, T. (2014). The impact of authoritative, authoritarian, and permissive parenting styles on children's later mental health in Japan: Focusing on parent and child gender. Journal of Child and Family Studies, 23, 293-302. doi:10.1007/s10826-0139740-3

*Van Ee, E., Sleijpen, M., Kleber, R. J., \& Jongmans, M. J. (2013). Father-involvement in a refugee sample: Relations between posttraumatic stress and caregiving. Family Process, 52, 723-735. doi:10.1111/famp.12045

Volker, J. (2014). Paternal involvement: A review of the factors influencing father involvement and outcomes. TCNJ Journal of Student Scholarship, 16, 1-8. Retrieved from http://joss.pages. tcnj.edu/files/2014/04/2014-Volker.pdf

*Waller, M. R., \& Bitler, M. P. (2008). The link between couples' pregnancy intentions and behavior: Does it matter who is asked? Perspectives on Sexual and Reproductive Health, 40(4), 194201. doi:10.1363/4019408

*Warpechowski, A., \& Mosmann, C. (2012). A experiência da paternidade frente à separação conjugal: Sentimentos e percepções [The experience of fatherhood followingmarital separation: Thoughts and feelings]. Temas em Psicologia, 20(1), 247-260. Retrieved from http://pepsic. bvsalud.org/pdf/tp/v20n1/v20n1a18.pdf

*Wysocki, T., \& Gavin, L. (2004). Psychometric properties of a new measure of fathers' involvement in the management of a pediatric chronic diseases. Journal of Pediatric Psychology, 29(3), 231-241. doi:10.1093/jpepsy/jsh024

Recebido: 21/09/2015

$1^{a}$ revisão: $14 / 04 / 2016$ Aceite final: 05/05/2016 